Journal for ImmunoTherapy of Cancer

\title{
Adenoviral vaccines promote protective tissue-resident memory $T$ cell populations against cancer
}

Esmé TI van der Gracht, ${ }^{1}$ Mark JA Schoonderwoerd, ${ }^{2}$ Suzanne van Duikeren, ${ }^{1}$ Ayse N Yilmaz, ${ }^{1}$ Felix M Behr, ${ }^{3}$ Julia M Colston, ${ }^{4}$ Lian N Lee, ${ }^{4}$ Hideo Yagita, ${ }^{5}$ Klaas PJM van Gisbergen, ${ }^{3}$ Lukas JAC Hawinkels, ${ }^{2}$ Frits Koning, ${ }^{1}$ Paul Klenerman, ${ }^{4}$ Ramon Arens (i) ${ }^{1}$
To cite: van der Gracht ETI, Schoonderwoerd MJA, van Duikeren S, et al. Adenoviral vaccines promote protective tissue-resident memory $T$ cell populations against cancer. Journal for ImmunoTherapy of Cancer 2020;8:e001133. doi:10.1136/jitc-2020-001133

Accepted 02 October 2020
Check for updates

(c) Author(s) (or their employer(s)) 2020. Re-use permitted under CC BY-NC. No commercial re-use. See rights and permissions. Published by BMJ.

${ }^{1}$ Department of Immunology, Leiden University Medical

Center, Leiden, The Netherlands

${ }^{2}$ Department of

Gasteroenterology and

Hepatology, Leiden University

Medical Center, Leiden, The

Netherlands

${ }^{3}$ Department of Hematopoiesis, Sanquin Research and

Landsteiner Laboratory,

Amsterdam, The Netherlands

${ }^{4}$ Nuffield Department of

Medicine, University of Oxford, Oxford, UK

${ }^{5}$ Department of Immunology, Juntendo University School of Medicine, Tokyo, Japan

Correspondence to

Dr Ramon Arens;

r.arens@lumc.nl

\section{ABSTRACT}

Background Adenoviral vectors emerged as important platforms for cancer immunotherapy. Vaccination with adenoviral vectors is promising in this respect, however, their specific mechanisms of action are not fully understood. Here, we assessed the development and maintenance of vaccine-induced tumor-specific $\mathrm{CD}^{+} \mathrm{T}$ cells elicited upon immunization with adenoviral vectors. Methods Adenoviral vaccine vectors encoding the fulllength E7 protein from human papilloma virus (HPV) or the immunodominant epitope from E7 were generated, and mice were immunized intravenously with different quantities $\left(10^{7}, 10^{8}\right.$ or $10^{9}$ infectious units). The magnitude, kinetics and tumor protection capacity of the induced vaccine-specific $\mathrm{T}$ cell responses were evaluated. Results The adenoviral vaccines elicited inflationary E7-specific memory $\mathrm{CD}^{+} \mathrm{T}$ cell responses in a dosedependent manner. The magnitude of these vaccinespecific $\mathrm{CD}^{+} \mathrm{T}$ cells in the circulation related to the development of E7-specific $\mathrm{CD}^{+}$tissue-resident memory $T\left(T_{R M}\right)$ cells, which were maintained for months in multiple tissues after vaccination. The vaccine-specific $\mathrm{CD}^{+} \mathrm{T}$ cell responses conferred long-term protection against HPV-induced carcinomas in the skin and liver, and this protection required the induction and accumulation of $\mathrm{CD}^{+} \mathrm{T}_{\mathrm{RM}}$ cells. Moreover, the formation of $\mathrm{CD}^{+} \mathrm{T}_{\mathrm{RM}}$ cells could be enhanced by temporal targeting CD80/CD86 costimulatory interactions via CTLA-4 blockade early after immunization.

Conclusions Together, these data show that adenoviral vector-induced $\mathrm{CD}^{+} \mathrm{T}$ cell inflation promotes protective $\mathrm{T}_{\mathrm{RM}}$ cell populations, and this can be enhanced by targeting CTLA-4.

\section{BACKGROUND}

After viral infection, naïve $\mathrm{CD} 8^{+} \mathrm{T}$ cells clonally expand and differentiate into effector cell populations, which turn into phenotypically diverse memory $\mathrm{CD}^{+} \mathrm{T}$ cell subsets that differ in their homing properties, cytokine polyfunctionality and cytolytic capacity. ${ }^{1}$ These memory $\mathrm{T}$ cell populations reside in the blood circulation, lymphoid organs but also in tissues, where they can become tissue-resident. ${ }^{2-5}$

Defining the protective cellular subsets and the crucial molecular interactions that induce sufficient effective $\mathrm{CD}^{+} \mathrm{T}$ cell memory pools at the right location is decisive for the design of successful vaccines against malignant disease. Recombinant adenoviral vectors are widely studied to induce immunity against viral infections. Adenovirus-based vaccines have been developed against respiratory syncytial virus and hepatitis $\mathrm{C}$ virus and demonstrated effective immunogenicity. ${ }^{6} 7$ Adenoviral vectors are currently strong candidate vaccines against the recently emerged SARS-CoV-2 causing the pandemic COVID$19 .^{8-11}$ Adenoviruses are also frequently used as platforms for gene therapy, oncolytic therapy and vaccines in cancer treatment. ${ }^{12}$ Regarding the cancer vaccine platform, several adenoviral vectors are currently in clinical trials for (preventive) treatment against prostate cancer, pancreatic cancer and human papilloma virus (HPV)-associated cancer. ${ }^{12}$ The utilization of adenoviral vectors as vaccines relates to their genome that can be genetically engineered. Replication-deficient adenoviral vectors are generated by deletion of early proteins $(\mathrm{E} 1 / \mathrm{E} 3)$ that are essential for viral replication. However, these vectors still allow considerable transgene expression. The absence of replication and the lack of integration of the vector genome, is linked to the safety of these vaccine vectors. ${ }^{1314}$ The tropism of the adenoviral vectors is broad, nonetheless on systemic administration the liver is a major site of infection. ${ }^{15-17}$

Moreover, adenoviral vaccine vectors are able to induce and sustain substantial memory $\mathrm{CD}^{+} \mathrm{T}$ cell populations. In experimental settings, recombinant replication-deficient HuAd5 vectors have been modified by a 
mini-gene strategy to express specific epitopes eliciting memory $\mathrm{T}$ cell inflation. ${ }^{819}$ Memory inflation, a characteristic of cytomegalovirus (CMV) infection, is typified by the maintenance of large populations of virus-specific $\mathrm{CD}^{+} \mathrm{T}$ cells with an effector-memory-like phenotype. ${ }^{2021}$ The low-level intermittent persistence of antigen is critical for the induction of inflationary memory responses, and importantly, the inflationary $\mathrm{CD}^{+} \mathrm{T}$ cells remain functional over time, which makes adenoviral vectors an ideal vaccine candidate. ${ }^{21}$ In contrast, chronic infections with high-level active replication elicit virus-specific exhausted $\mathrm{CD} 8^{+} \mathrm{T}$ cells. ${ }^{22}$ It became also apparent that both adenoviral vectors and CMV elicit circulating and tissue-resident memory $\mathrm{T}\left(\mathrm{T}_{\mathrm{RM}}\right)$ cells that are enriched in certain tissues. ${ }^{23-26}$ Whether memory $\mathrm{T}$ cell inflation is related to the formation and maintenance of $T_{R M}$ cells on adenoviral-vector vaccination is not fully understood. Furthermore, which cellular subset is critical for protection against cancer progression is unknown.

Here, we aim to understand the connection between memory $\mathrm{T}$ cell inflation and the induction of tissueresidency of $\mathrm{T}$ cells in an adenoviral vaccine setting, and in addition assess the protective capacity of circulating and $\mathrm{T}_{\mathrm{RM}}$ cell pools against solid tumors. We show that mice immunized with adenoviral vectors expressing the E7 oncogene of HPV or only the E7 immunodominant epitope induce high frequencies of circulating inflationary E7-specific $\mathrm{CD}^{+} \mathrm{T}$ cells, and the magnitude of these cells related to their development into $\mathrm{T}_{\mathrm{RM}}$ cells. In particular, these vaccine-induced $\mathrm{CD} 8^{+} \mathrm{T}_{\mathrm{RM}}$ cells provided long-term protection against HPV-positive tumors in the skin and liver, and enhancement of the $\mathrm{T}_{\mathrm{RM}}$ cell formation by temporal CTLA-4 blockade, improved suboptimal antitumor vaccination. Thus, the induction of $\mathrm{CD}^{+} \mathrm{T}$ cell tissue-residency by adenoviral vectors is linked to memory inflation, and this induction is essential for protection against solid tumors.

\section{METHODS \\ Mice}

C57BL/6 mice were obtained from Charles River Laboratories (L'Arbresle, France) or Jackson Laboratory (Sacramento, California, USA). $C d 70^{-/-27}$ and $C d 80 / 86^{-/-28}$ and Ly5.1 (CD45.1) mice were bred in house. At the start of the experiments, mice were 6 to 8 week-old. Animals were housed in individually-ventilated cages under specificpathogen free conditions at the animal facility at the Leiden University Medical Center (LUMC). All animal experiments were approved by the Animal Experiments Committee of LUMC and performed according to the recommendations and guidelines set by the LUMC and Dutch Experiments on Animals Act.

\section{Adenoviral vaccine vectors}

E1/E3-deleted replication-deficient adenoviral vectors (type 5) expressing full-length E7 (Ad-E7) or the E7 epitope (Ad-R9F) transgenes under control of the human
CMV promoter were produced at the Jenner Institute Viral Vector Core Facility (University of Oxford), as previously described. ${ }^{19}$ Expression cassettes were flanked by an initiator methionine, stop codon and a SV40 polyA tail. Peptide sequence full-length E7: MHGDTPTLHE YMLDLQPETT DLYCYEQLND SSEEEDEIDG PAGQAEPDRA HYNIVTFCCK CDSTLRLCVQ STHVDIRTLE DLLMGTLGIV CPICSQKP. Peptide sequence E7 epitope (R9F): RAHYNIVTF.

HEK293A T-Rex cells were transfected using linearized plasmid and the presence of the antigen gene was confirmed by PCR. The integrity of the antigenic DNA sequence and absence of contaminating adenovirus was confirmed by Flank-Flank PCR. The virus was titred to obtain infectious units (IU) per $\mathrm{mL}$, and assayed by spectrophotometry to quantify the number of virus particles per $\mathrm{mL}$. The P:I ratios of virus particles to infectivity were 25 (Ad-E7) and 40 (Ad-R9F). The sterility of the virus was also confirmed by inoculation of TSB broth with $10 \mu \mathrm{L}$ of purified virus and incubation for 3 days at $35^{\circ} \mathrm{C}$. Adenoviral vectors were stored at $-80^{\circ} \mathrm{C}$ and injected intravenously via the retro-orbital route at a dose of $10^{7}, 10^{8}$ or $10^{9}$ IU per mouse.

\section{Isolation of $\mathrm{T}_{\mathrm{RM}}$ cells}

Mice were perfused with $20 \mathrm{~mL}$ PBS containing $2 \mathrm{mM}$ EDTA to remove circulating blood cells from the organs of interest. The liver, lungs and tumors were cut into small pieces using surgical knives. The liver was resuspended in $3.5 \mathrm{~mL}$ IMDM containing $250 \mathrm{U} / \mathrm{mL}$ collagenase type 1-A (C2674, Sigma) and $20 \mu \mathrm{g} / \mathrm{mL}$ DNase I (D5025, Sigma). Lung tissue was incubated with $1 \mathrm{~mL}$ IMDM and $250 \mathrm{U} / \mathrm{mL}$ collagenase and $20 \mu \mathrm{g} / \mathrm{mL}$ DNase. For both liver and lungs, collagenase and DNase were incubated for $25 \mathrm{~min}$ at $37^{\circ} \mathrm{C}$. Tumors were incubated for $15 \mathrm{~min}$ at $37^{\circ} \mathrm{C}$ with IMDM-containing Liberase (\#05401020001, Roche). Single cell suspensions were made using $70 \mu \mathrm{m}$ cell strainers and subsequently lymphocytes were isolated using a Percoll gradient.

For intraepithelial lymphocyte (IEL) isolation, fat tissue and Peyer's patches were removed from the small intestine after which it was cut into $1 \mathrm{~cm}$ pieces. After washing, the intestine was incubated with $20 \mathrm{~mL}$ IMDM containing 10\% FCS, 5 mM EDTA and 1 mM DTT (D0632, Sigma) for $30 \mathrm{~min}$ at $37^{\circ} \mathrm{C}$. Supernatant containing the IEL fraction was isolated by filtering over a $70 \mu \mathrm{m}$ cell strainer and lymphocyte fractions were isolated using a Percoll gradient. For skin $\mathrm{T}$ cell isolation, first remaining hair was removed using Veet hair removal cream after which $1 \mathrm{~cm}$ by $1.5 \mathrm{~cm}$ skin tissue (located at the subcutaneous tumor site) was dissected. Skin tissue was incubated in 1.5 $\mathrm{mL}$ of $2.5 \mathrm{mg} / \mathrm{mL}$ Dispase II (D4693, Sigma) at $37^{\circ} \mathrm{C}$ for 1.5 hours. The skin tissue was cut into small pieces using surgical knives after which it was incubated in $1.5 \mathrm{~mL} 3$ $\mathrm{mg} / \mathrm{mL}$ collagenase type IV (C5138 Sigma) and $5 \mu \mathrm{g} / \mathrm{mL}$ DNAse I (D5025, Sigma) for $30 \mathrm{~min}$ at $37^{\circ} \mathrm{C}$. Single cell suspensions were made using $70 \mu \mathrm{m}$ cell strainers. 


\section{Tumor challenge models}

The TC-1 tumor cell line (a kind gift from T.C. Wu, John Hopkins University, Baltimore, MD) was developed by retroviral transduction of C57BL/6 lung epithelial cells with the HPV16 E6/E7 and c-H-ras oncogenes. ${ }^{29}$ The tumor cell line C3 was generated by transfection of mouse embryonic cells with the HPV16 genome and an activated-ras oncogene. ${ }^{30}$ Mice were inoculated subcutaneously in the flank with $1 \times 10^{5}$ TC- 1 tumor cells or $5 \times 10^{5}$ C3 tumor cells. Tumor size $\left(\mathrm{mm}^{3}\right)$ was measured two times a week using a caliper and calculated as $(\mathrm{L} \times \mathrm{W} \times \mathrm{H}) \times 0.52$ ( $\mathrm{L}$ : for length, W: width, H: height). Mice were euthanized when tumor size reached $500-1000 \mathrm{~mm}^{3}$ in volume. Mycoplasma tests were frequently performed by PCR and were negative for all cell lines. Cell lines were authenticated with a microsatellite PCR.

Luciferase-expressing TC-1 tumor cells were generated by transducing the TC-1 cells with a lentiviral vector expressing IRIS-GFP and the luciferase gene luc2. Before performing surgery, mice received $0.1 \mathrm{mg} /$ $\mathrm{kg}$ buprenorphine (Temgesic) subcutaneously as analgesia and isoflurane for anesthesia. After opening the peritoneum, the tip of the spleen was lifted to inject $1 \times 10^{5}$ TC-1-luc2 tumor cells in the spleen. To visualize tumor outgrowth by bioluminescence imaging, mice were injected intraperitoneally (IP) with $100 \mathrm{mg} / \mathrm{kg}$ D-luciferin (Synchem, Germany) and imaged after 10 min with the IVIS Spectrum Imager. Bioluminescence signals were measured twice a week starting from day 2 after tumor challenge.

\section{In vivo cytotoxicity assay}

The cytotoxicity of CD $8^{+} \mathrm{T}$ cells was assessed by transferring target cells (splenocytes from Ly5.1 (CD45.1) mice) that were prior differentially labeled with CFSE and peptide. Target cells were either CFSE high labeled $(5 \mu \mathrm{M})$ and then loaded with specific peptide (RAHYNIVTF) or were CFSE low labeled $(0.5 \mu \mathrm{M})$, and then loaded with a-specific peptide. Subsequently, the two target cell populations were mixed in a 1:1 ratio and injected intravenously into recipient mice. Recipient mice (wild-type C57BL/6 mice, Cd80/86 $/ 6^{-}$mice or mice containing CD70 blocking antibodies (clone FR70)) were either naive or were previously vaccinated with $10^{9}$ IU Ad-R9F for 50 days at the time of transfer. At 16 hours after transfer, the target cell killing in the spleens of recipient mice was determined by flow cytometry.

\section{Adoptive T cell transfers}

Spleens from Ly5.1 (CD45.1) mice were isolated and subsequently $\mathrm{CD}^{+}$effector-memory $\mathrm{T}\left(\mathrm{T}_{\mathrm{EM}}, \mathrm{CD} 44^{+} \mathrm{C}-\right.$ D62 $\left.\mathrm{L}^{-} \mathrm{CD} 69^{-}\right)$) and central-memory $\mathrm{T}\left(\mathrm{T}_{\mathrm{CM}}, \mathrm{CD} 44^{+} \mathrm{C}-\right.$ D62 $\left.\mathrm{L}^{+} \mathrm{CD} 69^{-}\right)$) cells were purified on a BD FACSAria cell sorter (BD Bioscience). $\mathrm{T}_{\mathrm{EM}}$ and $\mathrm{T}_{\mathrm{CM}}$ cells were adoptively transferred via retro-orbital injection into naive Ly5.2 mice, TC-1 tumor-bearing mice or into mice previously vaccinated with $10^{8}$ IU Ad-R9F.

\section{In vivo antibody and FTY720 treatment}

$\mathrm{CD}^{+} \mathrm{T}$ cell depleting monoclonal antibodies (clone 2.43) were administered twice per week, starting 4 days before tumor challenge, at $150 \mu \mathrm{g}$ per mouse by IP injection. For low-dose anti-CD8 treatment, $\mathrm{CD} 8^{+} \mathrm{T}$ cell depleting monoclonal antibodies (clone 2.43, Bio X Cell, West Lebanon, New Hampshire, USA) were administered twice per week, starting 4 days before tumor challenge, at $20 \mu \mathrm{g}$ per mouse by IP injection. To assess $\mathrm{CD} 8^{+} \mathrm{T}$ cell infiltration, the $\mathrm{CD} 8^{+} \mathrm{T}$ cells in the circulation were labeled by injecting mice retro-orbitally with $3 \mu \mathrm{g}$ CD8a APC (clone 53.6-7, BioLegend). After 3 min mice were sacrificed and subsequently tumor, spleen and liver were analyzed.

CTLA-4 (clone 9H10) monoclonal antibodies (Bio X Cell) were administered IP twice per week for 2 weeks starting at the day of infection at $200 \mu \mathrm{g}$ per mouse. CXCR3 (clone CXCR3-173, Bio X Cell) monoclonal antibodies were administered IP twice per week starting 4 days before tumor inoculation at $200 \mu \mathrm{g}$ per mouse. CD80 (clone RM80) and CD86 (clone P03.1) blocking antibodies $^{31}$ were administered IP two times per week at $300 \mu \mathrm{g}$ per mouse for 2 weeks starting the day of infection. CD70 (clone FR70) blocking antibody ${ }^{32}$ was administered IP twice a week at $150 \mu \mathrm{g}$ per mouse starting at the beginning of the experiment and continued for 3 weeks.

FTY720 (SML0700, SIGMA) was dissolved in $0,9 \% \mathrm{NaCl}$ and administered IP twice per week at $50 \mu \mathrm{g}$ starting 1 week before tumor challenge.

\section{Flow cytometry}

Fluorescently labeled monoclonal antibodies against the following mouse antigens were used: CD3 (clone 145-2 C11, BD Biosciences), CD4 (clone RM4-5, BioLegend), CD8a (clone 53-6.7, BioLegend), CD8b (clone YTS156.7.7, BioLegend), CD11a (clone M17/4, eBioscience), CD127 (clone A7R34, Thermo Fisher), KLRG-1 (clone 2F1, Thermo Fisher), CD44 (clone IM7, BioLegend), CD49a (clone Ha31/8, BD Biosciences), CD62L (clone MEL-14, BioLegend), CD69 (clone H1.2F3, BD Biosciences), CD38 (clone 90, Thermo Fisher) and CD103 (clone 2E7, Thermo Fisher). Cells were stained according to our previously published protocol. ${ }^{33}$ 7-AAD (A1310, Invitrogen) staining was used to exclude dead cells. E7-specific $\mathrm{CD} 8^{+} \mathrm{T}$ cells were quantified using MHC class I tetramers for the RAHYNIVTF epitope. Flow cytometric acquisition was performed on a BD Fortessa flow cytometer (BD Biosciences).

\section{Statistics}

Statistical analyzes were performed using GraphPad Prism (La Jolla, CA, Unites States). The One-way analysis of variance or Student's t-test was used for statistical analysis of unpaired data following a Gaussian (normal) distribution test. Difference in survival was tested with the log-rank (Mantel-Cox) survival test. All $\mathrm{P}$ values were two sided, and $\mathrm{P}<0.05$ was considered statistically significant. 
Van der Gracht et al. | Fig. 1.

A

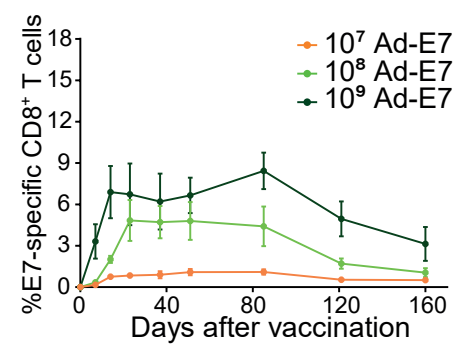

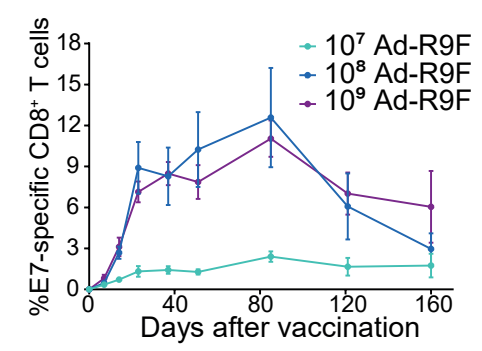

B
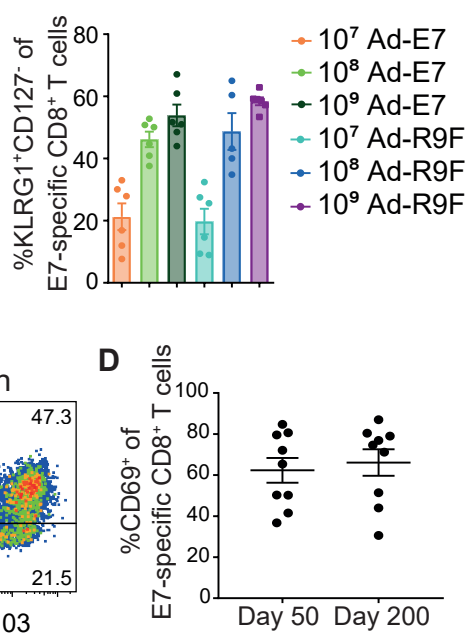

E
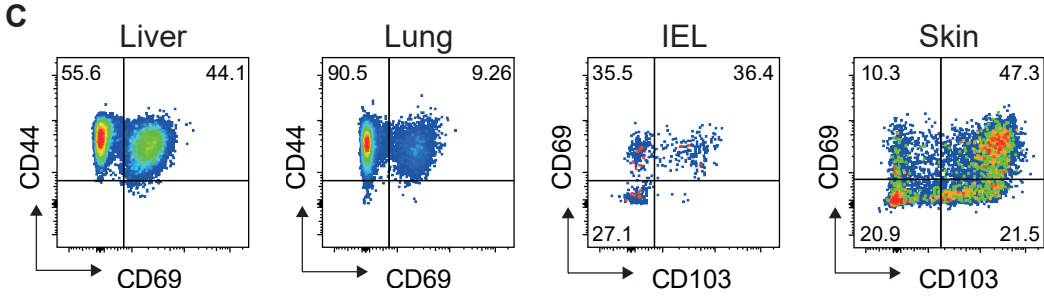

F
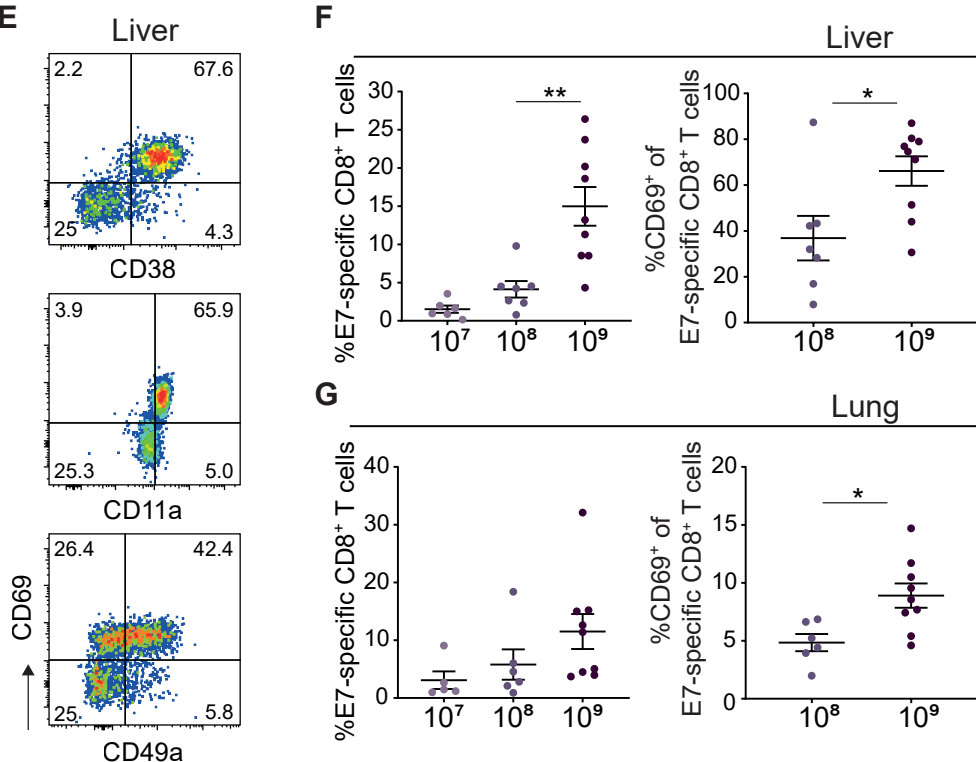

G

Lung
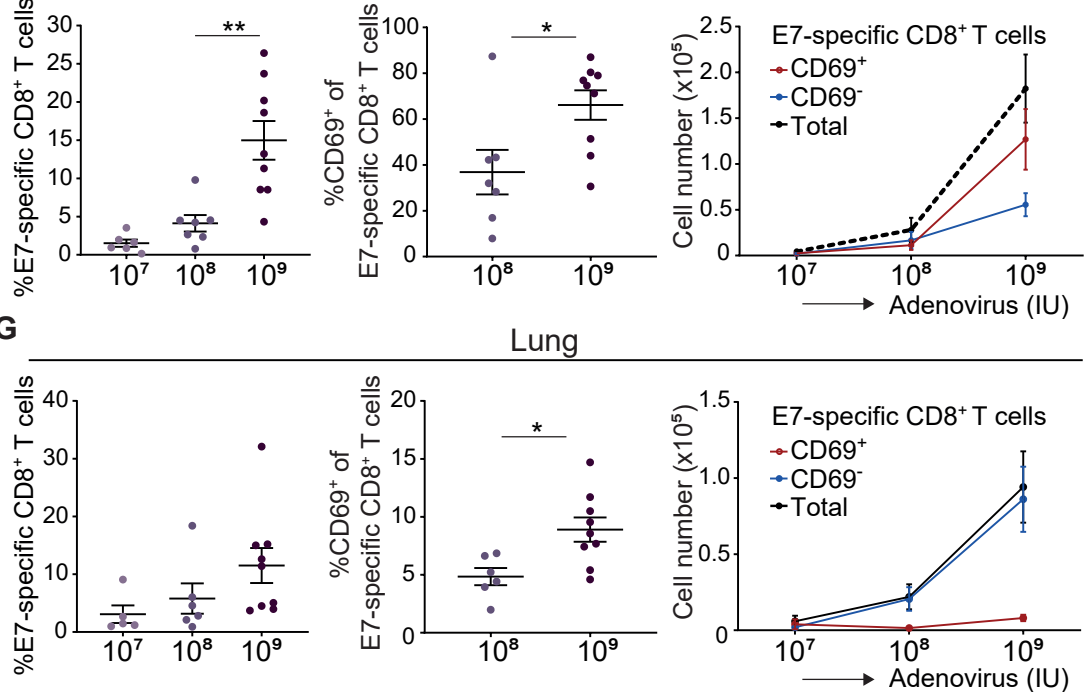

Figure 1 Adenoviral vaccine vectors induce memory $C D 8^{+} \mathrm{T}$ cell inflation and $\mathrm{T}_{\mathrm{RM}}$ cells. Mice were vaccinated IV with increasing dosages $\left(10^{7}, 10^{8}\right.$ or $\left.10^{9} \mathrm{IU}\right)$ of $\mathrm{Ad}-\mathrm{E} 7$ or $\mathrm{Ad}-\mathrm{R} 9 \mathrm{~F}$ vaccine vectors. E7-specific CD8 ${ }^{+} \mathrm{T}$ cells were longitudinally monitored with MHC class I tetramers. (A) Kinetics of E7-specific CD8 ${ }^{+} \mathrm{T}$ cells in blood. (B) Phenotype of E7-specific CD8 ${ }^{+} \mathrm{T}$ cells in blood at day 50 after vaccination. (C) E7-specific CD8 ${ }^{+} T_{R M}$ cells in liver, lung and IEL and CD8 ${ }^{+} T_{R M}$ cells in skin 200 days after $10^{9} \mathrm{IU}$ Ad-R9F vaccination. (D) Percentage of E7-specific CD8 ${ }^{+} T_{R M}$ cells in liver at day 50 and day 200 after $10^{9} \mathrm{IU}$ Ad-E7 or Ad-R9F vaccination. (E) Phenotype of E7-specific $\mathrm{CD}^{+} \mathrm{T}_{\mathrm{RM}}$ in liver at day 50 after Ad-R9F vaccination. (F, G) Percentage and absolute numbers of E7-specific $\mathrm{CD}^{+} \mathrm{T}$ cells and $\mathrm{T}_{\mathrm{RM}}$ cells after indicated doses of Ad-E7 or Ad-R9F in liver (F) and lung (G) 200 days after vaccination. Data shown are pooled from 2 to 3 independent experiments ( $n=3-5$ per group). Data are expressed as mean \pm SEM. One-way ANOVA (three groups) or Student t-test (two groups) was used for statistical analysis. ${ }^{*}<<0.05$, ${ }^{* *} \mathrm{P}<0.01$. ANOVA, analysis of variance; IEL, intraepithelial lymphocyte; IU, infectious units; $\mathrm{T}_{\mathrm{RM}}$, tissue-resident memory $\mathrm{T}$.

\section{RESULTS}

\section{Adenoviral vector vaccines induce $\mathrm{CDB}^{+} \mathrm{T}$ cell memory inflation and associated quantities of $\mathrm{T}_{\mathrm{RM}}$ cells}

Mice were immunized with different dosages of adenoviral vectors encoding full-length HPV E7 protein (Ad-E7) or the immunodominant epitope RAHYNIVTF from E7 (AdR9F). Vaccination with $10^{8}$ and $10^{9} \mathrm{IU}$ of Ad-E7 or Ad-R9F elicited high frequencies of circulating E7-specific $\mathrm{CD} 8^{+}$ $\mathrm{T}$ cell populations in the blood, that is, $4 \%-12 \%$ of the total $\mathrm{CD} 8^{+} \mathrm{T}$ cell population, which were maintained for months (figure 1A). In contrast, immunization with $10^{7}$
IU elicited E7-specific responses $<2 \%$. The higher vaccination dose correlated with an enhancement of circulating E7-specific $\mathrm{CD} 8^{+} \mathrm{T}$ cells with an effector-memory phenotype (ie, CD44 ${ }^{+} \mathrm{CD} 62 \mathrm{LCD}^{-}$127 KLRG1 ${ }^{+}$) (figure 1B and online supplemental figure 1A).

Next, we interrogated the impact of adenoviral vaccination on the development of E7-specific $\mathrm{CD}^{+} \mathrm{T}$ cells in multiple organs. E7-specific CD8 ${ }^{+} \mathrm{T}$ cells with a $\mathrm{T}_{\mathrm{RM}}$-like phenotype (ie, $\mathrm{CD}_{69^{+}}$or $\mathrm{CD} 69^{+} \mathrm{CD} 103^{+}$) were present in liver, lungs, intestine and skin (figure 1C and online supplemental figure 1B). Especially, in the liver large 
quantities of E7-specific $\mathrm{CD} 69^{+} \mathrm{CD} 8^{+} \mathrm{T}$ cells were induced, which were stably maintained for more than 200 days after vaccination (figure 1D). The E7-specific $\mathrm{CD} 69^{+} \mathrm{CD} 8^{+} \mathrm{T}$ cells in the liver also express other markers associated with $\mathrm{CD}^{+} \mathrm{T}$ cell tissue-residency such as CD38, CD11a and $\mathrm{CD} 49 \mathrm{a}$ (figure 1E). ${ }^{34-36}$ The adenovirus-vectored vaccines also elicited circulating effector-memory cells $\left(\mathrm{CD}_{4} 4^{+} \mathrm{CD} 62 \mathrm{LKLRG1}^{+} \mathrm{CD}^{-} 9^{-}\right)$in these organs. Remarkably, $\mathrm{T}_{\mathrm{RM}}$ cells increased particularly in the liver compared with the non-resident $\mathrm{CD}^{+} \mathrm{T}$ cells on high dose $\left(10^{9} \mathrm{IU}\right)$ vaccination. The increase in the total $\mathrm{E} 7$-specific $\mathrm{CD} 8^{+} \mathrm{T}$ cell population was mainly due to the rise in E7-specific $\mathrm{CD}^{+} \mathrm{T}_{\mathrm{RM}}$ cell numbers (figure $1 \mathrm{~F}$ ). In the lungs, mainly non-resident CD69- E7-specific CD8 ${ }^{+} \mathrm{T}$ cells are increased in numbers after high dose vaccination (figure 1G). Thus, high-dosed adenoviral vaccination elicits memory $\mathrm{T}$ cell inflation and specifically enhanced $\mathrm{T}_{\mathrm{RM}}$ cell formation in liver.

\section{Rapid conversion of circulating vaccine-elicited $\mathrm{CD8}^{+} \mathrm{T}$ cells into tissue-resident cells}

To assess whether the inflationary $\mathrm{CD}^{+} \mathrm{T}$ cells induced by adenoviral vectors have the capacity to migrate to the liver and differentiate into $\mathrm{T}_{\mathrm{RM}}$ cells, we performed adoptive transfers of the circulating $\mathrm{CD}^{+}$effectormemory $\left(\mathrm{T}_{\mathrm{EM}} ; \mathrm{CD}^{+} 4^{+} \mathrm{CD} 62 \mathrm{LCD}^{-}{ }^{-}\right.$) or central-memory $\left(\mathrm{T}_{\mathrm{CM}} ; \mathrm{CD} 44^{+} \mathrm{CD}^{-} \mathrm{L}^{+} \mathrm{CD} 69^{-}\right) \mathrm{T}$ cells (online supplemental figure 2A) from Ad-R9F vaccinated mice into naïve recipient mice or into recipient mice that where prior challenged with TC-1 tumor cells or prior vaccinated with Ad-R9F. When transferred into naive mice, the $\mathrm{T}_{\mathrm{EM}}$ and $\mathrm{T}_{\mathrm{CM}}$ subsets largely retain their phenotype in the liver after 14 days of transfer (figure 2A). However, in micebearing E7-expressing TC-1 tumors a substantial fraction of the transferred $\mathrm{T}_{\mathrm{EM}}$ cells differentiated within 10 days into liver $\mathrm{CD} 69^{+} \mathrm{T}_{\mathrm{RM}}$ cells (figure 2B and online supplemental figure 2B). This conversion was also evident in mice previously vaccinated with the same adenoviral vector (figure $2 \mathrm{C}$ and online supplemental figure $2 \mathrm{C}$ ). A portion of the E7-specific $\mathrm{CD}^{+} \mathrm{T}_{\mathrm{CM}}$ cells converted also converted into $\mathrm{T}_{\mathrm{RM}}$ cells, although this conversion was to a lower extent as compared with their effector-memory counterparts. Thus, adenoviral vaccine-induced E7-specific $\mathrm{CD}^{+} \mathrm{T}$ cells that circulate in the body can convert rapidly into cells with a $\mathrm{T}_{\mathrm{RM}}$ phenotype in an antigendependent manner.

\section{Adenoviral vector vaccination provides long-term $\mathrm{CD}^{+} \mathrm{T}$ cell dependent tumor protection}

To investigate the potential of Ad-E7 and Ad-R9F vaccine vectors to provide tumor protection, mice received a subcutaneous TC- 1 tumor challenge 50 days after vaccination. The strength of the vaccine-induced $\mathrm{CD} 8^{+} \mathrm{T}$ cell responses correlated with long-term protection against subcutaneously transplanted TC-1 tumors (figure 3A,B). To confirm the importance of the vaccine-induced CD8 ${ }^{+}$ $\mathrm{T}$ cells in tumor protection, these cells were specifically depleted by anti-CD8 antibodies. On $\mathrm{CD}^{+}{ }^{+} \mathrm{T}$ cell depletion, none of the vaccinated mice were protected (figure 3A,B). Subsequently, we validated in a second model the tumor protection efficacy of adenoviral vaccines. For this, we used the HPV16-transformed C3 tumor model. In this model, Ad-R9F vaccination resulted in substantial protection against C3 tumors in a dosedependent manner, and this protection also required $\mathrm{CD}^{+} \mathrm{T}$ cells (figure $3 \mathrm{C}, \mathrm{D}$ ). Thus, adenoviral vaccines elicit E7-specific $\mathrm{CD}^{+} \mathrm{T}$ cells that protect against subcutaneous tumors.

\section{The induction of $T_{R M}$ cells by adenoviral vectors is important for tumor protection}

To study the importance of circulating and tissueresident $\mathrm{CD}^{+} \mathrm{T}$ cells elicited by adenoviral vaccines for tumor protection, we trapped the circulating cells in the lymph nodes by the sphingosine 1-phosphate receptor modulator FTY $720^{37}$ or depleted either the circulating $\mathrm{CD}^{+} \mathrm{T}$ cells by low dose anti-CD8 antibody treatment or tissue-resident $\mathrm{CD}^{+} \mathrm{T}$ cells by CXCR3 antibodies (figure 4A,B). Compared with untreated vaccinated mice, FTY720 treatment resulted in a substantial reduction in tumor protection. Moreover, on low-dose anti-CD8 antibody treatment, none of the vaccinated mice were protected against tumor outgrowth (figure 4C,D). Both FTY720 treatment and low dose anti-CD8 affected the total amount of CD8 ${ }^{+}$ $\mathrm{T}$ cells in the circulation (figure $4 \mathrm{~A}$ ), and also those present in the tumor (online supplemental figure S3). Nevertheless, the few $\mathrm{CD} 8^{+} \mathrm{T}$ cells that were present in the tumor still converted into $\mathrm{T}_{\mathrm{RM}}$ cells, indicating that $\mathrm{T}_{\mathrm{RM}}$ formation is not blocked but severely limited and is likely due to limited infiltration from the circulation (online supplemental figure S3). Thus, diminishing the number of circulating $\mathrm{CD} 8^{+} \mathrm{T}$ cells prevent robust accumulation of $\mathrm{T}_{\mathrm{RM}}$ cells in the tumor, indicating that the circulating $\mathrm{CD} 8^{+} \mathrm{T}$ cells are an important source for sufficient formation of tumor-resident $\mathrm{CD} 8^{+} \mathrm{T}$ cells.

To directly study the role of $\mathrm{T}_{\mathrm{RM}}$ cells in tumor control, we tested whether CXCR3 antibodies, known to specifically deplete $T_{R M}$ cells in the liver, ${ }^{38}$ also deplete $\mathrm{T}_{\mathrm{RM}}$ cells in subcutaneous tumors. Treatment with CXCR3 antibodies resulted in a nearly complete depletion of liver $\mathrm{T}_{\mathrm{RM}}$ cells and also of $\mathrm{T}_{\mathrm{RM}}$ cells in the tumor(figure $4 \mathrm{~B}$ ), whereas $\mathrm{CD} 8^{+} \mathrm{T}$ cells in the circulation were not depleted (figure 4A). CXCR3 treatment did however not affect skin $\mathrm{T}_{\mathrm{RM}}$ (online supplemental figure $\mathrm{S} 4$ ), which corroborates the notion that circulation $\mathrm{CD}^{+} \mathrm{T}$ cells are vital for the formation of $\mathrm{T}_{\mathrm{RM}}$ cells in the tumor. To examine possible effects of CXCR3 antibody treatment on the migration of $\mathrm{CD} 8^{+} \mathrm{T}$ cells, we labeled the circulating $\mathrm{CD} 8^{+} \mathrm{T}$ cells by injecting APC-labeled CD8 antibodies $3 \mathrm{~min}$ before sacrifice. CXCR3 treatment did not alter the migration properties of $\mathrm{CD}^{+} \mathrm{T}$ cells in the tumor, spleen or liver (online supplemental figure S5). Taken together, CXCR3 antibody treatment does not affect $\mathrm{T}$ cell migration into tissues or the number of skin $T_{R M}$ cells but results in 
A

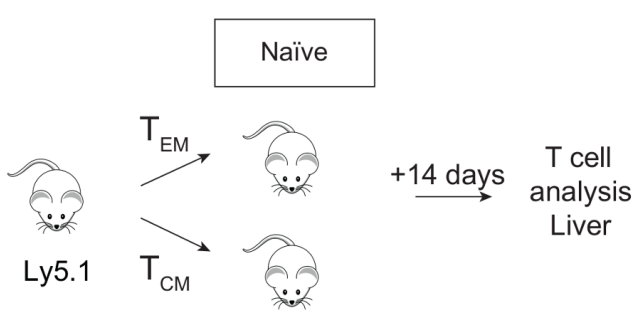

B

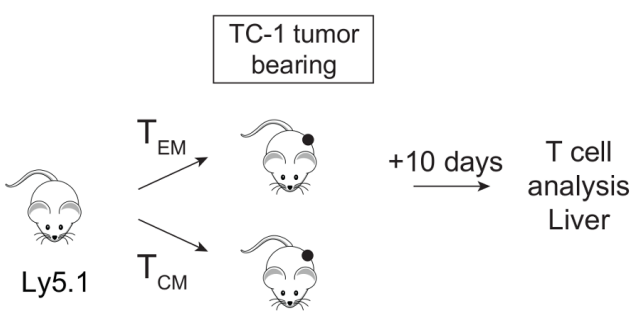

C

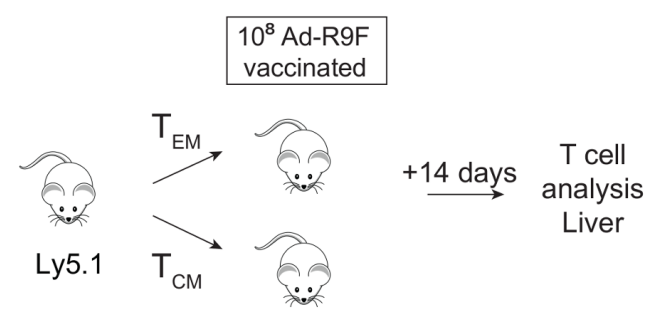

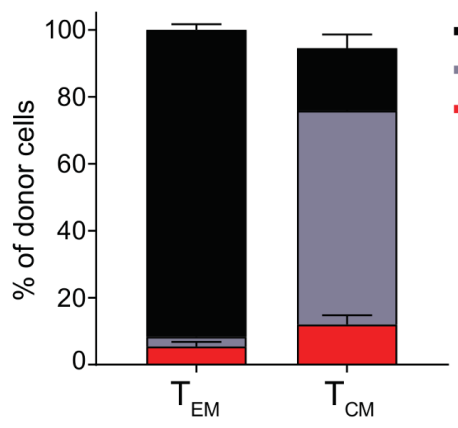

- CD69-CD62L

- CD69-CD62 ${ }^{\circ}$

- CD69+CD62L

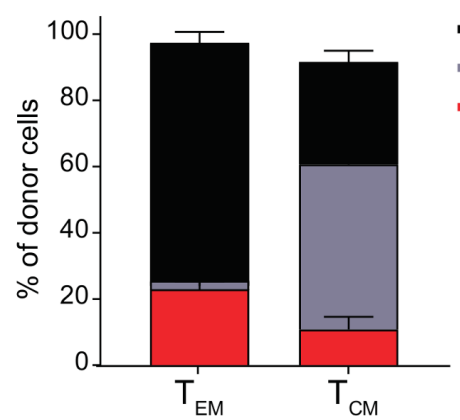

- CD69-CD62L-

- CD69-CD62L ${ }^{+}$

- $\mathrm{CD} 69^{+} \mathrm{CD} 62 \mathrm{~L}$

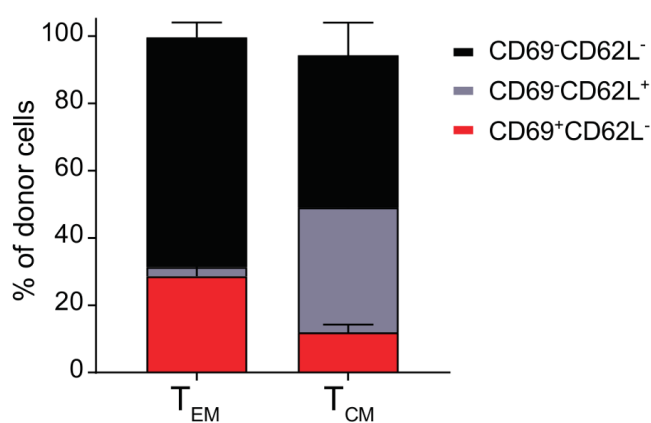

Figure 2 Circulating adenoviral vaccine-elicited $C D 8^{+} T$ cells convert rapidly into $T_{R M}$ cells. (A) Effector-memory $\left(T_{E M}\right.$; $\left.\mathrm{CD}_{4}{ }^{+} \mathrm{CD} 62 \mathrm{~L}^{-} \mathrm{CD} 69-\right)$ or central-memory $\left(\mathrm{T}_{\mathrm{CM}}\right.$; $\left.\mathrm{CD}_{4}{ }^{+} \mathrm{CD}^{-} \mathrm{L}^{+} \mathrm{CD}^{-}\right) \mathrm{CD}^{+} \mathrm{T}$ cells were isolated from infected Ly5.1 ( $\left.\mathrm{CD} 45.1^{+}\right)$ mice and adoptively transferred into naïve recipient mice, the distribution and phenotype of donor cells was analyzed 14 days

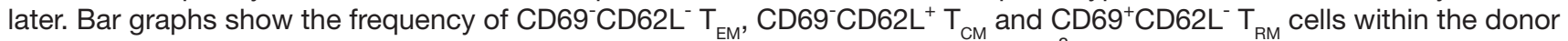
CD45. $1^{+}$CD8 $8^{+}$T cell population in the liver. (B) Ly5.1 mice were vaccinated with $10^{8} \mathrm{IU}$ Ad-R9F. At day 50 day, the $\mathrm{T}_{E M}$ or $\mathrm{T}_{\mathrm{CM}}$ $\mathrm{CD}^{+} \mathrm{T}$ cells were isolated and adoptively transferred into recipient mice, which were 10 days before transfer challenged with TC-1 tumor cells (subcutaneously in the flank). Bar graphs show the frequency of CD69-CD62L', CD69-CD62L $\mathrm{L}^{+}$and $\mathrm{CD}^{+}{ }^{+} \mathrm{CD}_{22} \mathrm{~L}^{-}$cells within the donor $\mathrm{CD} 45.1^{+} \mathrm{CD} 8^{+} \mathrm{T}$ cell population in the liver. (C) Ly5.1 (CD45.1 ${ }^{+}$) mice were vaccinated intravenously with $10^{8} \mathrm{IU}$ Ad-R9F. At day 50 day, the $\mathrm{T}_{E M}$ or $\mathrm{T}_{C M} C D 8^{+} \mathrm{T}$ cells were isolated and adoptively transferred into recipient mice, which were vaccinated intravenously with $10^{8} \mathrm{IU}$ Ad-R9F 23 days before transfer. Bar graphs show the frequency

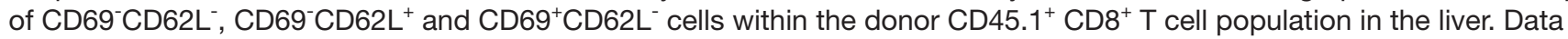
shown are from two independent experiments ( $n=6$ per group). Data are expressed as mean \pm SEM. IU, infectious units.

specific depletion of $\mathrm{T}_{\mathrm{RM}}$ cells in the tumor. Importantly, on the specific $\mathrm{T}_{\mathrm{RM}}$ cell depletion in the tumor by CXCR3 antibodies, Ad-R9F vaccination did not show any efficacy and all mice succumbed on tumor challenge (figure 4C,D).

To corroborate the importance of $\mathrm{T}_{\mathrm{RM}}$ cells for tumor protection, we setup a model to assess the efficacy of the E7-specific CD8 ${ }^{+} \mathrm{T}$ cell-eliciting adenoviral vectors against tumor development in the liver. Previous studies showed that on intrasplenic injection of tumor cells, the tumor cells are initially trapped in the liver vasculature followed by invasion of the surrounding tissue ${ }^{3940}$ By performing this procedure with luciferaseexpressing TC-1 tumor cells, we were able to track the metastatic tumor development in the liver by in vivo bioluminescence (figure $4 \mathrm{E}, \mathrm{F}$ ). In contrast to unvaccinated mice, $10^{9}$ IU Ad-R9F vaccinated mice, with intact numbers of $\mathrm{T}_{\mathrm{RM}}$ cells, were protected against liver tumor outgrowth. Strikingly, $\mathrm{T}_{\mathrm{RM}}$ depletion in vaccinated mice resulted in considerable outgrowth of the tumor cells (figure $4 \mathrm{G}$ ). Thus, $\mathrm{T}_{\mathrm{RM}}$ cells mediate critical immunity against tumors growing in the skin and liver. 
A

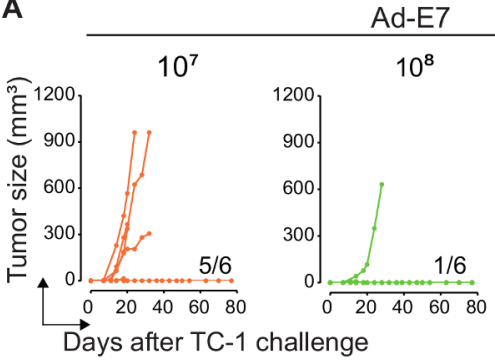

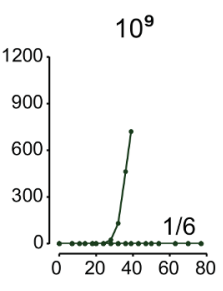
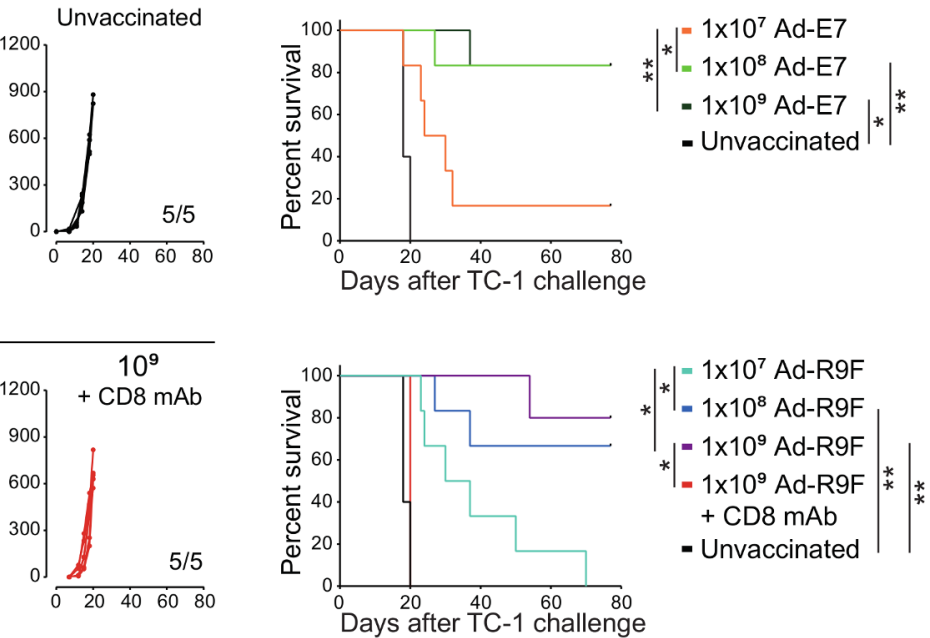

D
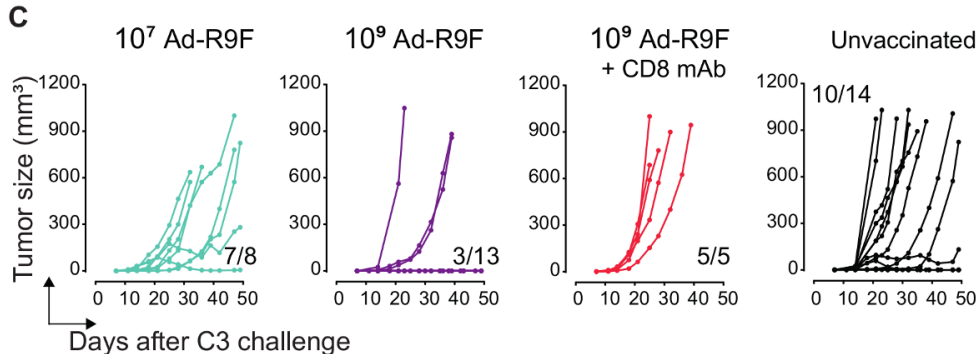

Figure $3 \mathrm{CD}^{+} \mathrm{T}$ cells are essential for adenoviral vector-mediated protection against subcutaneous tumors. Mice were vaccinated intravenously with increasing dosages $\left(10^{7}, 10^{8}\right.$ or $\left.10^{9} \mathrm{IU}\right)$ of $\mathrm{Ad}-\mathrm{E} 7$ or $\mathrm{Ad}-\mathrm{R} 9 \mathrm{~F}$ vaccine vectors. Tumor outgrowth (A) and survival (B) of mice challenged with TC-1 tumor cells (subcutaneously in the flank) at day 160 after vaccination. CD8 depleting antibodies (150 $\mathrm{gg}$ IP) were administered twice per week starting 4 days before tumor challenge. (C, D) Tumor outgrowth (C) and survival (D) of mice challenged with $\mathrm{C} 3$ tumor cells (subcutaneously in the flank) at day 50 after vaccination with $10^{7}$ or $10^{9} \mathrm{IU}$ Ad-R9F. CD8 depleting antibodies $(150 \mu \mathrm{g}$ IP) were injected 4 days before tumor challenge. Data shown are from two pooled experiments ( $n=3-8$ per group). Log-rank (Mantel-Cox) survival test was performed. ${ }^{\star} P<0.05,{ }^{* *} P<0.01$. IU, infectious units.

\section{Costimulatory requirements for inflationary E7-specific CD8 ${ }^{+}$ $T$ cell responses and $T_{R M}$ cell formation}

Costimulatory molecules regulate $\mathrm{T}$ cell activation and differentiation, and can serve as therapeutic targets for modulating $\mathrm{T}$ cell responses. At day 3 after adenoviral vector vaccination, the costimulatory molecules CD80 and CD86 were upregulated on $\mathrm{CD} 11 \mathrm{~b}^{+} \mathrm{CD} 11 \mathrm{c}^{+}$cells in the liver (figure 5A). To directly dissect the role of CD80/CD86-mediated costimulation in the induction of memory inflation and the formation of $\mathrm{T}_{\mathrm{RM}}$ cells after adenovirus-vector vaccination, we evaluated mice deficient in these costimulatory molecules and in addition abrogated CD80/CD86 interactions at different time points post $10^{9} \mathrm{IU}$ Ad-R9F vaccination using blocking antibodies. $C d 80 / 86^{-}$mice were not able to generate inflationary E7-specific $\mathrm{CD}^{+} \mathrm{T}$ cell responses in the blood after Ad-R9F vaccination (figure 5B). Consistently, in adenovirus-vector vaccinated wild-type mice, but not in vaccinated $C d 80 / 86^{--}$mice, a functional cytolytic E7-specific $\mathrm{CD}^{+} \mathrm{T}$ cell response was generated that killed $\mathrm{E} 7^{+}$target cells in vivo (figure $5 \mathrm{C}, \mathrm{D}$ ). Blockade of CD80/CD86-mediated costimulation at different time points after adenovirus-vector vaccination indicated that predominantly the initial CD80/ CD86 interactions are required for the initiation of inflationary $\mathrm{E} 7$-specific $\mathrm{CD}^{+} \mathrm{T}$ cell responses in the blood (figure 5B). The deprived E7-specific $\mathrm{CD}^{+}$ $\mathrm{T}$ cell response in mice with deficient CD80/CD86mediated costimulation, related to a complete lack of E7-specific $\mathrm{CD}^{+} \mathrm{T}_{\mathrm{RM}}$ cell formation in liver and lungs of these mice (figure 5E). In contrast to CD80/CD86, CD70 was not upregulated on vaccination and consistently the abrogation of CD70 did not affect the generation or cytolytic function of $\mathrm{E} 7$-specific $\mathrm{CD} 8^{+} \mathrm{T}$ cells in the circulation or in the tissues (figure 5A-E). Thus, in particular CD80/CD86-mediated costimulation is essential for the inflationary E7-specific $\mathrm{CD}^{+} \mathrm{T}$ cell response and development of $\mathrm{T}_{\mathrm{RM}}$ cell formation on adenoviral vaccination.

\section{Enhancement of $\mathrm{T}_{\mathrm{RM}}$ cell formation by CTLA-4 blockade leads to delayed tumor outgrowth}

Next, we evaluated whether enhancing CD80/86mediated costimulation by blocking the inhibitory 
A

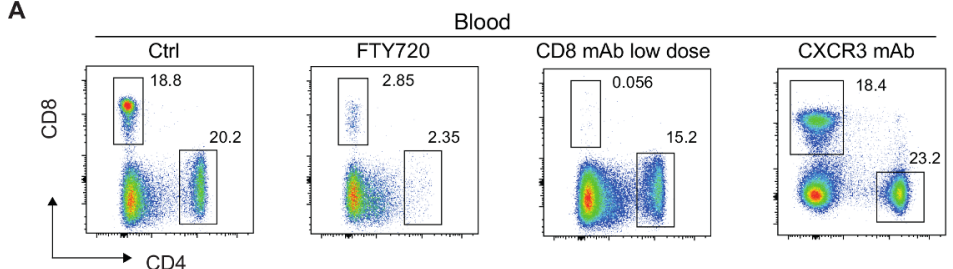

c

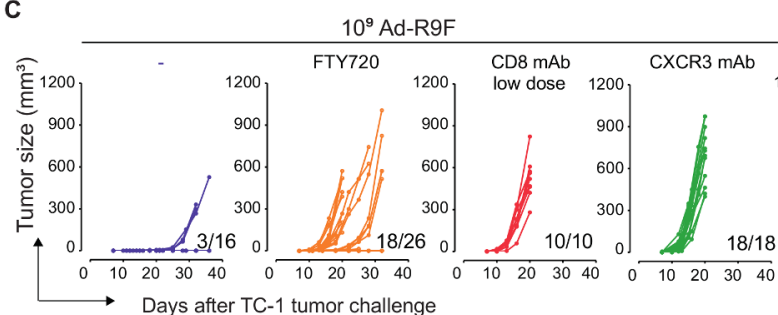

E

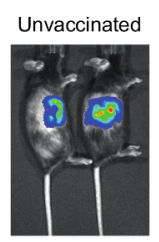

F

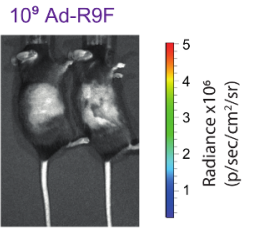

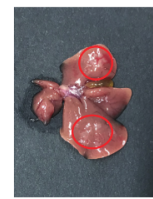

G

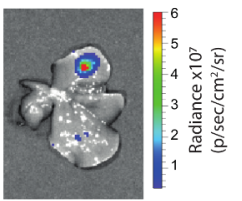

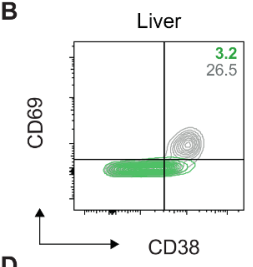

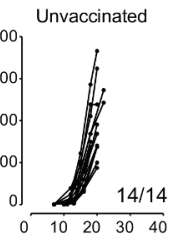

D
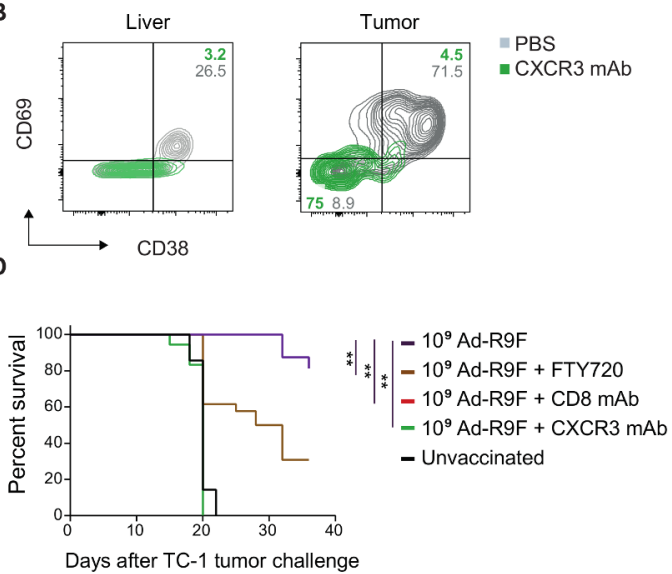

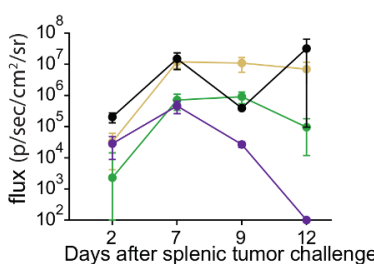

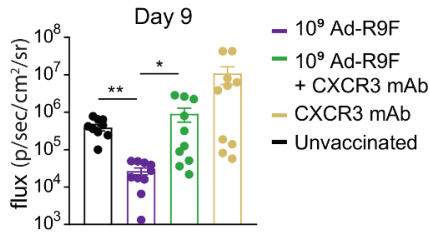

$-10^{9} \mathrm{Ad}-\mathrm{R} 9 \mathrm{~F}$ $10^{9}$ Ad-R9F
+ CXCR3 mAb CXCR3 mAb - Unvaccinated

Figure $4 T_{R M}$ cells are important for adenovirus-mediated tumor protection. (A) Percentage of CD8 ${ }^{+} \mathrm{T}$ cells of total blood lymphocytes in untreated (Ctrl) mice or in mice treated for 2 weeks with FTY720, low-dose anti-CD8 mAb or CXCR3 antibodies.

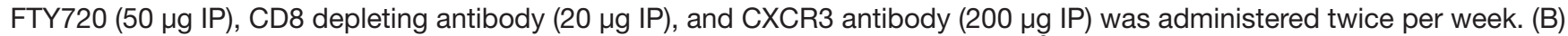
Expression of CD69 and CD38 on E7-specific CD8 ${ }^{+}$T cells in liver and tumor of $10^{9} \mathrm{IU}$ Ad-R9F intravenously vaccinated mice that were challenged with TC-1 tumor cells at day 50 post-vaccination and treated twice per week (starting 4 days before tumor challenge) with a depleting CXCR3 antibody (200 $\mu \mathrm{g} \mathrm{IP})$. Analysis was performed at day 20 post-tumor challenge. (C, D) Tumor outgrowth $(C)$ and survival (D) of mice challenged with TC-1 tumor cells (subcutaneously in the flank) at day 50 after intravenous vaccination with $10^{9} \mathrm{IU}$ Ad-R9F. FTY720 (50 $\mu \mathrm{g}$ IP), low-dose CD8 depleting antibody $(20 \mu \mathrm{g}$ IP) or CXCR3 depleting antibody (200 $\mu \mathrm{g}$ IP) was administered twice per week starting 4 days before tumor challenge. Data are pooled from 2 independent experiments ( $n=6-9$ per group). (E) Mice were vaccinated intravenously with $10^{9} \mathrm{IU}$ Ad-R9F and 44 days postvaccination received luciferase-containing TC-1 (TC-1-luc2) tumor cells in the spleen, which metastasize to the liver. Shown are bioluminescence signals of unvaccinated and $10^{9} \mathrm{IU}$ Ad-R9F vaccinated mice at day 7 after TC-1-luc2 splenic tumor challenge. (F) Image and bioluminescence signal of a representative liver from unvaccinated mouse at day 12 after TC-1-luc2 splenic tumor challenge. Bioluminescence signals were absent in all livers of vaccinated mice. (G) CXCR3 depleting antibody $(200 \mu \mathrm{g} \mathrm{IP})$ was administered twice per week starting 4 days before splenic tumor challenge. Bioluminescence flux at liver side at indicated time points after tumor challenge is shown ( $n=10$ per group). Data are expressed as mean $\pm S E M$. One-way ANOVA was used for statistical analysis. Log-rank (Mantel-Cox) survival test is performed for survival data. ${ }^{*} \mathrm{P}<0.05,{ }^{*} \mathrm{P}<0.01$. ANOVA. analysis of variance; IU, infectious units.

receptor CTLA-4, which competes with CD28 for CD80/86, could positively impact the formation of adenoviral vaccine-elicited $\mathrm{CD}^{+} \mathrm{T}_{\mathrm{RM}}$ cells, and hence the protection against subcutaneous tumors. To create a therapeutic window, mice were vaccinated with $10^{7}$ IU Ad-R9F and subsequently treated with CTLA-4 blocking antibodies during the first 2 weeks after vaccination. Blockade of CTLA-4 delayed tumor outgrowth as compared with control treated vaccinated mice, and this delay of tumor outgrowth was dependent on $\mathrm{T}_{\mathrm{RM}}$ cells (figure 6A,B). Although CTLA-4 blockade resulted in similar frequencies of circulating E7-specific $\mathrm{CD} 8^{+} \mathrm{T}$ cells, a large portion of these cells displayed an effector-memory phenotype (figure 6C). Moreover, the formation of $\mathrm{CD}^{+} \mathrm{T}_{\mathrm{RM}}$ cells in the liver was enhanced by CTLA-4 blockade (figure 6D). Thus, temporal improving CD80/CD86-mediated costimulation increases $\mathrm{CD}^{+} \mathrm{T}_{\mathrm{RM}}$ cell formation leading to delayed tumor outgrowth.

\section{DISCUSSION}

Here, we show that adenoviral vaccine vectors expressing E7 antigens from HPV induce E7-specific memory inflation and associated formation of $\mathrm{T}_{\mathrm{RM}}$ cells. In particular, $\mathrm{T}_{\mathrm{RM}}$ cell development was instrumental in providing protection against subcutaneous tumors and metastasized tumors in the liver. To this end, it was unknown which cellular subsets induced on adenoviral vaccination are implicated in protection. The induction of memory inflation and ensuing $\mathrm{T}_{\mathrm{RM}}$ development depended on early CD80/CD86-mediated costimulatory interactions, and enhancing this costimulatory communication by blocking the interaction of CD80/CD86 with the 
A

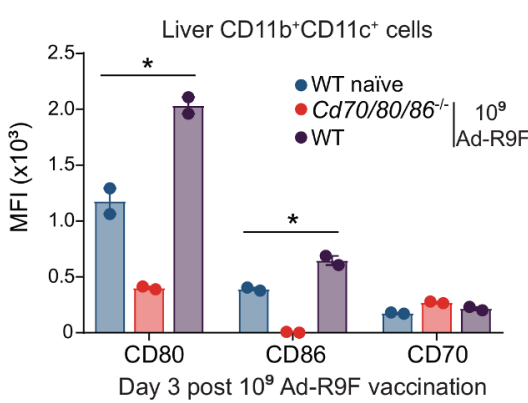

Day 3 post $10^{9} \mathrm{Ad}-\mathrm{R} 9 \mathrm{~F}$ vaccination

D

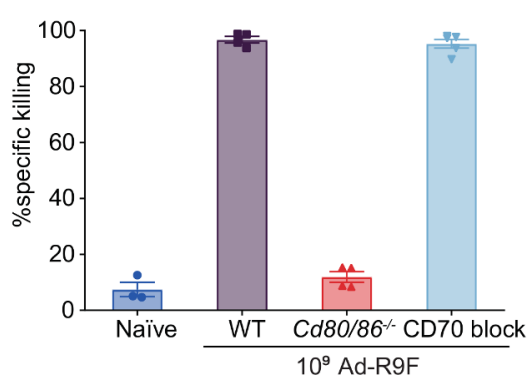

B

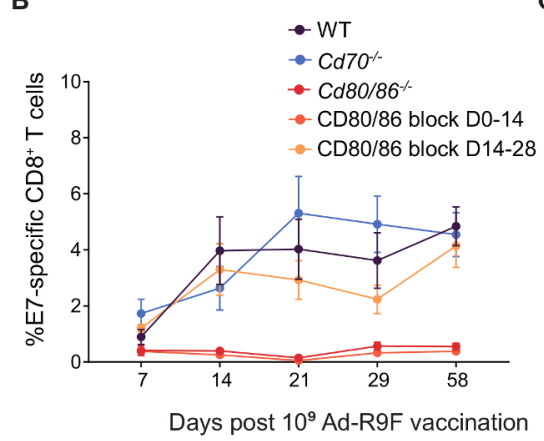

C

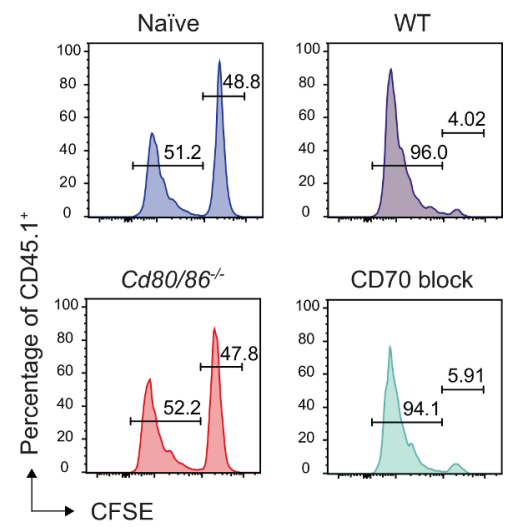

Lung
$E$

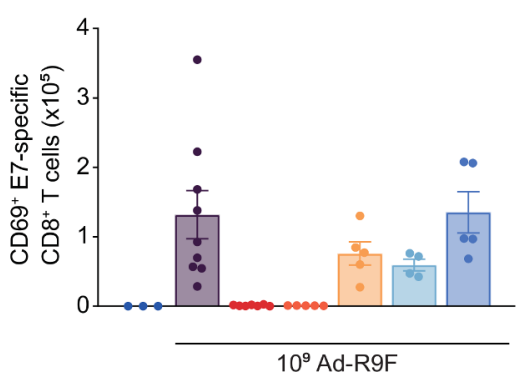

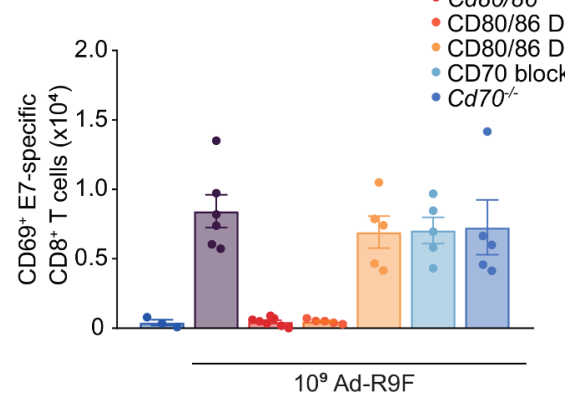

Figure 5 CD80/86-mediated costimulation is required for the development of inflationary E7-specific CD8 ${ }^{+} T$ cell responses and $T_{R M}$ cell formation. (A) Expression levels of CD80, CD86 and CD70 on CD11 b ${ }^{+}$CD11 ${ }^{+}$cells in the liver 3 days postintravenous vaccination with $10^{9} \mathrm{IU}$ Ad-R9F. One-way ANOVA was used for statistical analysis. ${ }^{*} P<0.05$. Experiments were performed twice with similar outcome. (B) Kinetics of E7-specific CD8 ${ }^{+} \mathrm{T}$ cells after $10^{9} \mathrm{IU}$ Ad-R9F intravenous vaccination. CD80/86 or CD70 blocking antibodies were administered during indicated time periods. (C) In vivo cytotoxicity assay. Target ratio of specific (CFSE high) and non-specific (CFSE low) peptide-loaded CD45.1 $1^{+}$splenocytes 1 day after adoptive transfer in C57BL/6 mice 50 days after $10^{9} \mathrm{IU}$ Ad-R9F vaccination. (D) In vivo cytotoxicity assay. Percentage of specific killing of target CD45. $1^{+}$cells. (E) E7-specific CD8 ${ }^{+} \mathrm{T}_{\mathrm{RM}}$ cell numbers in the liver and lung at day 50 post $10^{9} \mathrm{IU}$ Ad-R9F intravenous vaccination. Data are expressed as mean \pm SEM. ANOVA, analysis of variance; IU, infectious units.

inhibitory receptor CTLA-4, improved $\mathrm{T}_{\mathrm{RM}}$ cell formation leading to increased protection.

We used replication-deficient adenoviral vaccine vectors ${ }^{18}{ }^{19}$ modified to elicit $\mathrm{CD}^{+} \mathrm{T}$ cell responses against the E7 oncogene of HPV as a traceable model to study the development of tumor-specific memory $\mathrm{T}$ cell populations and their connection to protection. Large populations of circulating E7-specific memory $\mathrm{CD}^{+} \mathrm{T}$ cells with an effector-memory-like phenotype were maintained on high-dose vaccination. This resembles CMV infection, where the viral inoculum dose determines the degree of memory T cell inflation. ${ }^{21}{ }^{41}$ In contrast to CMV, adenoviral-vectors do not replicate, however, antigen likely persists at low levels. Bolinger $e t$ al showed that even without replication of the adenoviral vaccines, low-level antigen is expressed at late time points after vaccination. This persistence of antigen after vaccination was tested by adoptive transfer of CFSE-labeled TCR transgenic $\mathrm{CD}^{+} \mathrm{T}$ cells into previously vaccinated recipients. ${ }^{18}$ Even 100 days after vaccination, adoptively transferred $\mathrm{T}$ cells became activated and proliferated. Although the induction pathway of inflationary adenoviral induced $\mathrm{T}$ cells is distinct from inflationary CMV-specific $\mathrm{T}$ cells, the sustained memory inflation induced by adenoviral vectors and CMV is closely related, in both mouse and human. ${ }^{42}$ Strikingly, we found that the induction and magnitude of inflationary $\mathrm{CD}^{+} \mathrm{T}$ cells is linked to an increase in $\mathrm{T}_{\mathrm{RM}}$ cells.

For various infections, the route of infection is crucial for the magnitude and location of $T_{R M}$ cell formation (reviewed in $^{44}$ ). Consistent with the liver being the site of infection on systemic administration of the adenoviral vaccine, ${ }^{15-17}$ we found that $\mathrm{E}$ 7-specific $\mathrm{CD} 8^{+} \mathrm{T}_{\mathrm{RM}}$ cells were stably maintained in the liver for months after adenoviral vaccination. The antigen persistence in the liver on adenoviral vector immunization may explain both the phenomenon of memory $\mathrm{T}$ cell inflation as well as the maintenance of liver $\mathrm{T}_{\mathrm{RM}}$ cells, since $\mathrm{T}_{\mathrm{RM}}$ cell formation is linked to memory inflation and the $\mathrm{T}_{\mathrm{RM}}$ cells can be enhanced by both local antigen presentation and inflammation. ${ }^{45-49}$

Previously, Ad35-based vectors eliciting E7-specific T cell responses showed protection against subcutaneous tumor protection but the mode of action remained unclear. ${ }^{50}{ }^{51}$ Here, we found for the first time a crucial role for $\mathrm{T}_{\mathrm{RM}}$ cells for the adenovirus-mediated tumor protection in both liver and skin. CMV-based vaccines can also mediate tumor protection and this correlates to 
A

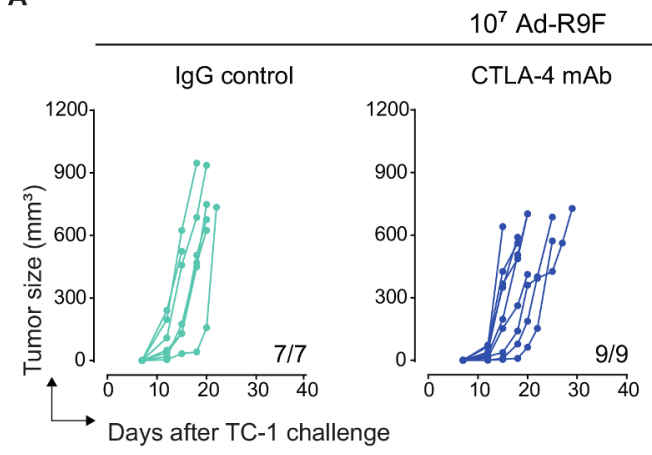

C

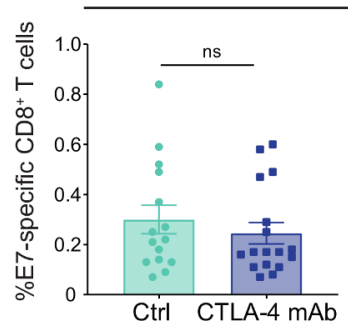

Blood

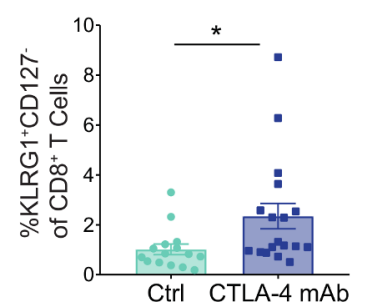

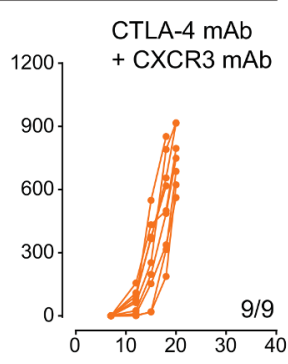

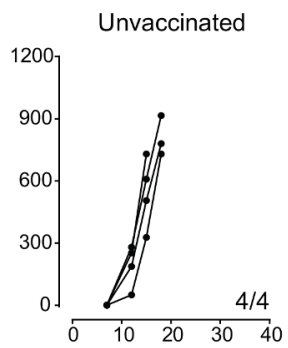

B
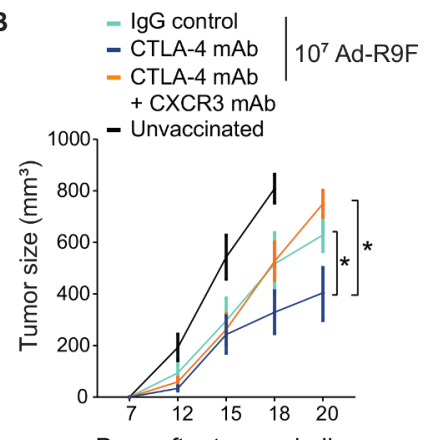

Days after tumor challenge

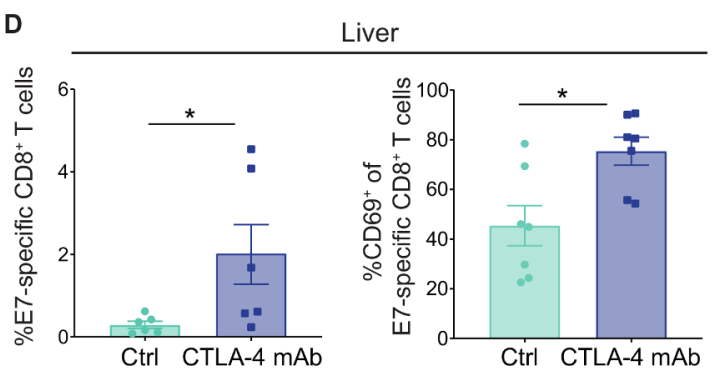

Figure 6 Enhancement of $T_{R M}$ cell formation by CTLA-4 targeting leads to delayed tumor outgrowth. (A) Tumor outgrowth of mice challenged with TC-1 tumor cells (subcutaneously in the flank) at day 50 after $10^{7} \mathrm{IU}$ Ad-R9F intravenous vaccination. CTLA-4 monoclonal antibody $(200 \mu \mathrm{g}$ IP) was administered twice per week for two weeks starting the day of vaccination. CXCR3 depleting antibody (200 $\mu \mathrm{g}$ IP) and control IgG antibody (200 $\mu \mathrm{g}$ IP) were administered twice per week starting 4 days before tumor challenge. (B) Mean tumor size of mice intravenous vaccinated with $10^{7} \mathrm{IU}$ Ad-R9F, and treated with CTLA-4, CXCR3 or control IgG antibody IP. (C) Percentage and phenotype of CD8 ${ }^{+} \mathrm{T}$ cells in blood 21 days after intravenous vaccination with $10^{7} \mathrm{IU}$ Ad-R9F and treatment with blocking CTLA-4 antibody (200 $\mu \mathrm{g}$ IP). (D) Percentage of E7-specific CD8 ${ }^{+} \mathrm{T}$ cells and E7-specific CD8 ${ }^{+} T_{R M}$ cells in the liver at day 50 post vaccination and treatment with blocking CTLA-4 antibody (200 $\mu$ IP). CTLA-4 blockade was provided for two weeks post vaccination. Data shown are pooled from 2 independent experiments ( $\mathrm{n}=3-$ 6 per group). One-way ANOVA or Student's t-test was used for statistical analysis. Data are expressed as mean \pm SEM. ${ }^{\star} \mathrm{P}<0.05$, ${ }^{\star *} \mathrm{P}<0.01$. ANOVA, analysis of variance; IP, intraperitoneally; IU, infectious units; ns, not significant

circulating inflationary $\mathrm{CD} 8^{+} \mathrm{T}$ cells, ${ }^{52}$ but whether $\mathrm{T}_{\mathrm{RM}}$ cells are implicated for protection is unknown. Circulating $\mathrm{T}$ cells are also important, and our results indicate that these cells are a crucial source for the formation of tumor-resident $\mathrm{CD}^{+} \mathrm{T}$ cells. Recombinant vaccinia viruses also mediate tumor protection that rely on both circulating and $\mathrm{T}_{\mathrm{RM}}$ cells, and collaboration between these subsets leads to optimal antitumor immunity. ${ }^{53}$

The characteristics of effector and memory antigenspecific $\mathrm{CD}^{+} \mathrm{T}$ cell responses are shaped by pathogenspecific differential utilization of costimulatory pathways. ${ }^{54}$ Herein, we demonstrate that the initial expansion of adenovirus-vectored vaccine-specific $\mathrm{CD} 8^{+}$ $\mathrm{T}$ cells depends completely on CD80/CD86 costimulatory interactions, which is dissimilar to the induction of memory inflation on MCMV infection. ${ }^{33}$ In addition, CD70-mediated costimulation is redundant for adenoviral induced $\mathrm{T}$ cell responses whereas this type of costimulation is important for the development of mouse CMV-specific T cell immunity. ${ }^{55}$ CTLA-4 generates inhibitory signals that counteract the costimulation provided via CD28 by competing directly with CD28 for its ligands CD80/CD86, ${ }^{56}{ }^{57}$ but CTLA-4 can also actively remove its ligands CD80/CD86 by internalizing them for degradation. ${ }^{58}$ Blocking CTLA-4 is thought to promote especially the priming of $\mathrm{CD}^{+} \mathrm{T}$ cells. ${ }^{59}{ }^{60}$ In line with an early impact of CD80/CD86 costimulatory interactions, we here show that initial targeting of CTLA- 4 after immunization increases $\mathrm{CD} 8^{+} \mathrm{T}_{\mathrm{RM}}$ cells and therefore also protective immunity. It is of interest to further explore whether directly targeting CD28 or targeting other costimulatory receptors could also lead to enhanced $\mathrm{T}_{\mathrm{RM}}$ cell formation.

To conclude, here we show that $\mathrm{CD}^{+} \mathrm{T}_{\mathrm{RM}}$ cells are an important protective cellular subset induced by adenoviral vectors. Moreover, the formation of $\mathrm{T}_{\mathrm{RM}}$ cells is linked to the magnitude of memory inflation in the circulation, and this process can be enhanced by targeting CD28mediated costimulation. Thereby, this study provides new insights for future development of adenoviral vaccine strategies with an emphasis on the induction of $\mathrm{T}_{\mathrm{RM}}$ cells.

Acknowledgements We would like to thank K. Franken (LUMC) for generating MHC class I tetramers. We thank Dr. T.C. van der Sluis and G. Beyrend for their technical assistance with experiments.

Contributors EG and RA contributed to the study conceptualization and study design. EG, MS, SD, AY and FB performed data acquisition. JC, LL, HY, KG, LH, FK, PK were involved in developing methodology and interpretation of data. The manuscript was written by EG and RA and edited by all authors. RA supervised the study.EG and RA contributed to the study conceptualization and study design. EG, MS, SD, AY and FB performed data acquisition. JC, LL, HY, KG, LH, FK, PK were 
involved in developing methodology and interpretation of data. The manuscript was written by EG and RA and edited by all authors. RA supervised the study.

Competing interests No, there are no competing interests.

Patient consent for publication Not required.

Provenance and peer review Not commissioned; externally peer reviewed.

Data availability statement All data relevant to the study are included in the article or uploaded as online supplemental information. All data generated or analyzed during this study are included in this published article and its additional file.

Supplemental material This content has been supplied by the author(s). It has not been vetted by BMJ Publishing Group Limited (BMJ) and may not have been peer-reviewed. Any opinions or recommendations discussed are solely those of the author(s) and are not endorsed by BMJ. BMJ disclaims all liability and responsibility arising from any reliance placed on the content. Where the content includes any translated material, BMJ does not warrant the accuracy and reliability of the translations (including but not limited to local regulations, clinical guidelines, terminology, drug names and drug dosages), and is not responsible for any error and/or omissions arising from translation and adaptation or otherwise.

Open access This is an open access article distributed in accordance with the Creative Commons Attribution Non Commercial (CC BY-NC 4.0) license, which permits others to distribute, remix, adapt, build upon this work non-commercially, and license their derivative works on different terms, provided the original work is properly cited, appropriate credit is given, any changes made indicated, and the use is non-commercial. See http://creativecommons.org/licenses/by-nc/4.0/.

\section{ORCID iD}

Ramon Arens http://orcid.org/0000-0001-5058-4110

\section{REFERENCES}

1 Arens R, Schoenberger SP. Plasticity in programming of effector and memory CD8 T-cell formation. Immunol Rev 2010;235:190-205.

2 Schenkel JM, Fraser KA, Masopust D. Cutting edge: resident memory CD8 T cells occupy frontline niches in secondary lymphoid organs. J Immunol 2014;192:2961-4.

3 Masopust D, Choo D, Vezys V, et al. Dynamic T cell migration program provides resident memory within intestinal epithelium. J Exp Med 2010;207:553-64.

4 Gebhardt T, Wakim LM, Eidsmo L, et al. Memory T cells in nonlymphoid tissue that provide enhanced local immunity during infection with herpes simplex virus. Nat Immunol 2009;10:524-30.

5 Casey KA, Fraser KA, Schenkel JM, et al. Antigen-Independent differentiation and maintenance of effector-like resident memory $T$ cells in tissues. J Immunol 2012;188:4866-75.

6 Cicconi P, Jones C, Sarkar E, et al. First-In-Human randomized study to assess the safety and immunogenicity of an investigational respiratory syncytial virus (RSV) vaccine based on ChimpanzeeAdenovirus-155 viral Vector-Expressing RSV fusion, nucleocapsid, and antitermination viral proteins in healthy adults. Clin Infect Dis 2020;70:2073-81.

7 Barnes E, Folgori A, Capone S, et al. Novel adenovirus-based vaccines induce broad and sustained $\mathrm{T}$ cell responses to HCV in man. Sci Trans/ Med 2012;4:3003155.

8 Wu S, Zhong G, Zhang J, et al. A single dose of an adenovirusvectored vaccine provides protection against SARS-CoV-2 challenge. Nat Commun 2020;11:4081.

9 Mercado NB, Zahn R, Wegmann F, et al. Single-shot Ad26 vaccine protects against SARS-CoV-2 in rhesus macaques. Nature 2020. doi:10.1038/s41586-020-2607-z. [Epub ahead of print: 30 Jul 2020].

10 Folegatti PM, Ewer KJ, Aley PK, et al. Safety and immunogenicity of the ChAdOx1 nCoV-19 vaccine against SARS-CoV-2: a preliminary report of a phase 1/2, single-blind, randomised controlled trial. Lancet 2020;396:467-78.

11 Zhu F-C, Li Y-H, Guan X-H, et al. Safety, tolerability, and immunogenicity of a recombinant adenovirus type-5 vectored COVID-19 vaccine: a dose-escalation, open-label, non-randomised, first-in-human trial. Lancet 2020;395:1845-54.

12 Shaw AR, Suzuki M. Immunology of adenoviral vectors in cancer therapy. Mol Ther Methods Clin Dev 2019;15:418-29.

13 Van Kampen KR, Shi Z, Gao P, et al. Safety and immunogenicity of adenovirus-vectored nasal and epicutaneous influenza vaccines in humans. Vaccine 2005;23:1029-36.

14 Catanzaro AT, Koup RA, Roederer M, et al. Phase 1 safety and immunogenicity evaluation of a multiclade HIV-1 candidate vaccine delivered by a replication-defective recombinant adenovirus vector. $J$ Infect Dis 2006;194:1638-49.

15 Schweichel D, Steitz J, Tormo D, et al. Evaluation of DNA vaccination with recombinant adenoviruses using bioluminescence imaging of antigen expression: impact of application routes and delivery with dendritic cells. J Gene Med 2006;8:1243-50.

16 Holst PJ, Ørskov C, Thomsen AR, et al. Quality of the transgenespecific CD8+ T cell response induced by adenoviral vector immunization is critically influenced by virus dose and route of vaccination. J Immunol 2010;184:4431-9.

17 Sullivan DE, Dash S, Du H, et al. Liver-directed gene transfer in nonhuman primates. Hum Gene Ther 1997;8:1195-206.

18 Bolinger B, Sims S, O'Hara G, et al. A new model for CD8+ T cell memory inflation based upon a recombinant adenoviral vector. J Immunol 2013;190:4162-74.

19 Colston JM, Bolinger B, Cottingham MG, et al. Modification of antigen impacts on memory quality after adenovirus vaccination. $\mathrm{J}$ Immunol 2016;196:3354-63.

20 Klenerman P, Oxenius A. T cell responses to cytomegalovirus. Nat Rev Immunol 2016;16:367-77.

21 O'Hara GA, Welten SPM, Klenerman P, et al. Memory T cell inflation: understanding cause and effect. Trends Immunol 2012;33:84-90.

22 Cicin-Sain L, Arens R. Exhaustion and inflation at antipodes of $\mathrm{T}$ cell responses to chronic virus infection. Trends Microbiol 2018;26:498-509.

23 Smith CJ, Caldeira-Dantas S, Turula H, et al. Murine CMV infection induces the continuous production of mucosal resident T cells. Cell Rep 2015;13:1137-48.

24 Thom JT, Weber TC, Walton SM, et al. The Salivary Gland Acts as a Sink for Tissue-Resident Memory CD8(+) T Cells, Facilitating Protection from Local Cytomegalovirus Infection. Cell Rep 2015;13:1125-36.

25 Zaric M, Becker PD, Hervouet C, et al. Long-lived tissue resident HIV-1 specific memory CD8 ${ }^{+} \mathrm{T}$ cells are generated by skin immunization with live virus vectored microneedle arrays. J Control Release 2017;268:166-75.

26 Lapuente D, Storcksdieck Genannt Bonsmann M, Maaske A, et al. IL-1 $\beta$ as mucosal vaccine adjuvant: the specific induction of tissueresident memory $\mathrm{T}$ cells improves the heterosubtypic immunity against influenza A viruses. Mucosal Immunol 2018;11:1265-78.

27 Coquet JM, Middendorp S, van der Horst G, et al. The CD27 and CD70 costimulatory pathway inhibits effector function of T helper 17 cells and attenuates associated autoimmunity. Immunity 2013;38:53-65.

28 Borriello F, Sethna MP, Boyd SD, et al. B7-1 and B7-2 have overlapping, critical roles in immunoglobulin class switching and germinal center formation. Immunity 1997;6:303-13.

29 Lin KY, Guarnieri FG, Staveley-O'Carroll KF, et al. Treatment of established tumors with a novel vaccine that enhances major histocompatibility class II presentation of tumor antigen. Cancer Res 1996;56:21-6.

30 Feltkamp MC, Smits HL, Vierboom MP, et al. Vaccination with cytotoxic T lymphocyte epitope-containing peptide protects against a tumor induced by human papillomavirus type 16-transformed cells. Eur J Immunol 1993;23:2242-9.

31 Nuriya S, Yagita H, Okumura K, et al. The differential role of CD86 and CD80 co-stimulatory molecules in the induction and the effector phases of contact hypersensitivity. Int Immunol 1996;8:917-26.

32 Oshima $\mathrm{H}$, Nakano $\mathrm{H}$, Nohara $\mathrm{C}$, et al. Characterization of murine CD70 by molecular cloning and mAb. Int Immunol 1998;10:517-26.

33 Arens R, Loewendorf A, Redeker A, et al. Differential B7-CD28 costimulatory requirements for stable and Inflationary mouse cytomegalovirus-specific memory CD8 T cell populations. J Immunol 2011;186:3874-81.

34 McNamara HA, Cai Y, Wagle MV, et al. Up-regulation of LFA-1 allows liver-resident memory $T$ cells to patrol and remain in the hepatic sinusoids. Sci Immunol 2017;2:eaaj1996.

35 Topham DJ, Reilly EC. Tissue-Resident memory CD8 ${ }^{+} \mathrm{T}$ cells: from phenotype to function. Front Immunol 2018;9:515.

36 Stark R, Wesselink TH, Behr FM, et al. TRM maintenance is regulated by tissue damage via P2RX7. Sci Immunol 2018;3:eaau1022.

37 Morris MA, Gibb DR, Picard F, et al. Transient T cell accumulation in lymph nodes and sustained lymphopenia in mice treated with FTY720. Eur J Immunol 2005;35:3570-80.

38 Fernandez-Ruiz D, Ng WY, Holz LE, et al. Liver-Resident Memory $\mathrm{CD}^{+} \mathrm{T}$ Cells Form a Front-Line Defense against Malaria Liver-Stage Infection. Immunity 2016;45:889-902.

39 Oh BY, Hong HK, Lee WY, et al. Animal models of colorectal cancer with liver metastasis. Cancer Lett 2017;387:114-20.

40 Paauwe M, Schoonderwoerd MJA, Helderman RFCP, et al. Endoglin expression on cancer-associated fibroblasts regulates invasion 
and stimulates colorectal cancer metastasis. Clin Cancer Res 2018;24:6331-44.

41 Redeker A, Welten SPM, Arens R. Viral inoculum dose impacts memory T-cell inflation. Eur J Immunol 2014:44:1046-57.

42 Gordon CL, Hutchings CL, Highton AJ, et al. Memory inflation following adenoviral vaccination depends on IL-21. Vaccine 2018;36:7011-6.

43 Bolinger B, Sims S, Swadling L, et al. Adenoviral Vector Vaccination Induces a Conserved Program of CD8(+) T Cell Memory Differentiation in Mouse and Man. Cell Rep 2015;13:1578-88.

44 Park CO, Kupper TS. The emerging role of resident memory T cells in protective immunity and inflammatory disease. Nat Med 2015;21:688-97.

45 Holz LE, Prier JE, Freestone D, et al. CD8 ${ }^{+}$T Cell Activation Leads to Constitutive Formation of Liver Tissue-Resident Memory T Cells that Seed a Large and Flexible Niche in the Liver. Cell Rep 2018;25:68-79.

46 Davies B, Prier JE, Jones CM, et al. Cutting edge: tissueresident memory $T$ cells generated by multiple immunizations or localized deposition provide enhanced immunity. J Immunol 2017;198:2233-7.

47 Khan TN, Mooster JL, Kilgore AM, et al. Local antigen in nonlymphoid tissue promotes resident memory CD8+ T cell formation during viral infection. J Exp Med 2016;213:951-66.

48 Bergsbaken T, Bevan MJ, Fink PJ. Local Inflammatory Cues Regulate Differentiation and Persistence of $\mathrm{CD}^{+}$Tissue-Resident Memory T Cells. Cell Rep 2017;19:114-24.

49 Mackay LK, Stock AT, Ma JZ, et al. Long-Lived epithelial immunity by tissue-resident memory T (TRM) cells in the absence of persisting local antigen presentation. Proc Natl Acad Sci U S A 2012;109:7037-42.

50 Khan S, Oosterhuis K, Wunderlich K, et al. Development of a replication-deficient adenoviral vector-based vaccine candidate for the interception of HPV16- and HPV18-induced infections and disease. Int J Cancer 2017:141:393-404.

51 Çuburu N, Khan S, Thompson CD, et al. Adenovirus vectorbased prime-boost vaccination via heterologous routes induces cervicovaginal $\mathrm{CD} 8^{+} \mathrm{T}$ cell responses against HPV16 oncoproteins. Int J Cancer 2018;142:1467-79.

52 Beyranvand Nejad E, Ratts RB, Panagioti E, et al. Demarcated thresholds of tumor-specific CD8 T cells elicited by MCMV-based vaccine vectors provide robust correlates of protection. $\mathrm{J}$ Immunother Cancer 2019;7:25.

53 Enamorado M, Iborra S, Priego E, et al. Enhanced anti-tumour immunity requires the interplay between resident and circulating memory CD8 ${ }^{+}$T cells. Nat Commun 2017;8:16073.

54 Welten SPM, Redeker A, Franken KLMC, et al. The viral context instructs the redundancy of costimulatory pathways in driving CD8(+) T cell expansion. Elife 2015;4. doi:10.7554/eLife.07486. [Epub ahead of print: 11 Aug 2015].

55 Welten SPM, Redeker A, Franken KL, et al. CD27-CD70 costimulation controls $\mathrm{T}$ cell immunity during acute and persistent cytomegalovirus infection. J Virol 2013;87:6851-65.

56 Collins AV, Brodie DW, Gilbert RJC, et al. The interaction properties of costimulatory molecules revisited. Immunity 2002;17:201-10.

57 Krummel MF, Allison JP. CD28 and CTLA-4 have opposing effects on the response of T cells to stimulation. J Exp Med 1995;182:459-65.

58 Qureshi OS, Zheng Y, Nakamura K, et al. Trans-endocytosis of CD80 and CD86: a molecular basis for the cell-extrinsic function of CTLA4. Science 2011;332:600-3.

59 Kvistborg P, Philips D, Kelderman S, et al. Anti-CTLA-4 therapy broadens the melanoma-reactive CD8+ T cell response. Sci Transl Med 2014;6:254ra128.

60 Pedicord VA, Montalvo W, Leiner IM, et al. Single dose of antiCTLA-4 enhances CD8+ T-cell memory formation, function, and maintenance. Proc Natl Acad Sci U S A 2011;108:266-71. 